\title{
A protein kinase $C \beta$ inhibitor attenuates multidrug resistance of neuroblastoma cells
} Karin Svensson ${ }^{1,2}$ and Christer Larsson*1

\author{
Address: ${ }^{1}$ Molecular Medicine, Lund Univeristy, Entrance 78, 3rd floor, Malmö University Hospital, SE-205 02 Malmö, Sweden and ${ }^{2}$ Present \\ address: Cell Biology and Biochemistry HB3 AstraZeneca R\&D Mölndal SE-431 83 Mölndal Sweden \\ Email: Karin Svensson - Karin.J.Svensson@astrazeneca.com; Christer Larsson* - Christer.Larsson@molmed.mas.lu.se \\ * Corresponding author
}

Published: 26 March 2003

BMC Cancer 2003, 3:10

This article is available from: http://www.biomedcentral.com/I47/-2407/3/10

(C) 2003 Svensson and Larsson; licensee BioMed Central Ltd. This is an Open Access article: verbatim copying and redistribution of this article are permitted in all media for any purpose, provided this notice is preserved along with the article's original URL.
Received: 21 December 2002

Accepted: 26 March 2003

\begin{abstract}
Background: The acquisition of drug resistance is a major reason for poor outcome of neuroblastoma. Protein kinase C (PKC) has been suggested to influence drug resistance in cancer cells. The aim of this study was to elucidate whether inhibition of $P K C \beta$ isoforms influences drugresistance of neuroblastoma cells.

Methods: The effect of the PKC $\beta$ inhibitor LY379/96 on the growth-suppressing effects of different chemotherapeutics on neuroblastoma cells was analyzed with MTT assays. The effect of LY379| 96 on the accumulation of $\left[{ }^{3} \mathrm{H}\right]$ vincristine was also investigated

Results: The PKC $\beta$ inhibitor LY379196 suppressed the growth of three neuroblastoma cell lines. LY379196 also augmented the growth-suppressive effect of doxorubicin, etoposide, paclitaxel, and vincristine, but not of carboplatin. The effect was most marked for vincristine and for the cell-line (SK-N-BE(2)) that was least sensitive to vincristine. No effect was observed on the non-resistant IMR-32 cells. Two other PKC inhibitors, Gö6976 and GFI09203X, also enhanced the vincristine effect. The PKC inhibitors caused an increased accumulation of $\left[{ }^{3} \mathrm{H}\right]$ vincristine in $\mathrm{SK}-\mathrm{N}-\mathrm{BE}(2)$ cells.
\end{abstract}

Conclusions: This indicates that inhibition of $\mathrm{PKC} \beta$ could attenuate multidrug resistance in neuroblastoma cells by augmenting the levels of natural product anticancer drugs in resistant cells.

\section{Background}

Neuroblastoma is a childhood tumor originating from the peripheral sympathetic nervous system. It is characterized of two different patterns of disease progress. One, frequently occurring in very young children and without amplification of the MYCN gene, is often associated with good prognosis and sometimes even with spontaneous regression. The other group of tumors, however, often involving slightly older children and with MYCN amplification is associated with poor prognosis [1]. A common feature of highly malignant neuroblastoma is the acquisition of multidrug resistance [2].
Protein kinase C (PKC) constitutes a family of closely related protein serine/threonine kinase which are subgrouped into classical (PKC $\alpha, \beta I, \beta I I$, and $\gamma$ ), novel (PKC $\delta$, $\varepsilon, \eta$, and $\theta$ ), and atypical ( $\mathrm{PKC} \mathrm{a}$ and $\zeta$ ) isoforms. The basis for this classification is different domain structure and activator requirements of the isoforms [3]. The members of the PKC family are involved in the regulation of numerous cell processes including proliferation, apoptosis, and differentiation. It is likely that each isoform has a specific role in a given cell. 
We have shown that neuroblastoma cells express $P K C \alpha$, $\beta \mathrm{I}$, and $\beta \mathrm{II}$ of the classical isoforms and PKC $\delta$ and $\varepsilon$ of the novel isoforms $[4,5]$. Of these isoforms PKC $\varepsilon$ is a positive regulator of neurite outgrowth during differentiation of these cells $[6,7]$ whereas PKC $\beta$ I seems to have a positive role for neuroblastoma cell proliferation [5]. The latter study also indicated that inhibition of $\mathrm{PKC} \beta$ could potentiate the growth suppressive effect of microtubule-interacting anticancer drugs.

The aim of this study was to investigate whether inhibition of PKC $\beta$ isoforms could be utilized to potentiate the effects of chemotherapeutic drugs on neuroblastoma cells. For that purpose three cell lines, one without MYCN amplification (SH-SY5Y), and two MYCN-amplified (IMR-32 and SK-N-BE(2)), were screened for the combinatorial effects of the PKC $\beta$ inhibitor and several chemotherapeutic drugs. One of these cell lines, SK-N-BE(2), has been shown to exhibit resistance to a broad range of anticancer compounds.

We found that the specific PKC $\beta$ inhibitor LY379196 suppressed the growth of all three neuroblastoma cell lines studied and that it potentiated the growth-suppressive effect of all investigated chemotherapeutics, except carboplatin, on the drug-resistant SK-N-BE(2) cell line. Furthermore, LY379196 potentiated the accumulation of $\left[{ }^{3} \mathrm{H}\right]$ vincristine in the SK-N-BE(2) cells suggesting that an effect on the elimination of the chemotherapeutic drugs is the mechanism whereby LY379196 influences the effect on cell growth.

\section{Methods \\ Cell lines}

IMR-32, SH-SY5Y, and SK-N-BE(2) neuroblastoma cells were maintained in Eagle's minimal essential medium supplemented with $10 \%$ FCS, $100 \mathrm{IU} / \mathrm{ml}$ penicillin and $100 \mu \mathrm{g} / \mathrm{ml}$ streptomycin (all cell culture reagents were from Gibco).

\section{Cell viability analysis}

Cells were seeded at a density of 5000 cells per well in 96 well plates and cultured for three (SK-N-BE(2)) or four (IMR-32 and SH-SY5Y) days. Drugs had been added to the wells prior to addition of cells. LY379196 (kindly provided by Eli Lilly Research Laboratories), GF109203X and Gö6976 (Calbiochem), and etoposide and paclitaxel (Sigma) were solubilized in DMSO. Vincristine (Sigma) and carboplatin and doxorubicin (ICN) were solubilized in water. The amount of viable cells in the wells were analyzed with an MTT assay (Promega) according to the supplier's protocol. To calculate the drug concentration that gives $50 \%$ viable cells compared to control conditions a non-linear curve fit, $y=A_{2}-\left(A_{1}-A_{2}\right) /(1+B / x)$, was performed on the experimental data. With the parameter val- ues obtained from the curve fit, we calculated the anticancer drug concentration that reduced the amount of viable cells to $50 \%$. This was done in two ways to both show the effect of LY379196 on the potency of the chemotherapeutic drug and to illustrate the total effect of the combination of LY379196 and the chemotherapeutic drug on neuroblastoma cell growth. In the first case, the amount of cells in the absence of chemotherapeutic drug but in the presence of the particular LY379196 concentration was set to $100 \%$, and the concentration of anticancer drug that gave $50 \%$ was calculated. In the second case, the amount of cells in the absence of both PKC inhibitor and chemotherapeutic drug was set to $100 \%$. For each LY379196 concentration, the concentration of chemotherapeutic drug that suppressed the amount of cells to $50 \%$ was thereafter calculated.

\section{Accumulation of $\left[^{3} \mathrm{H}\right]$ vincristine}

SK-N-BE(2) cells were seeded at a density of 100,000 cells/ well in a 24-well plate. The next day PKC inhibitors were added at indicated concentrations and $15 \mathrm{~min}$ later $\left[{ }^{3} \mathrm{H}\right]$ vincristine (final concentration $1 \mu \mathrm{M}, 0.25 \mathrm{Ci} / \mathrm{mmol}$ [Amersham Pharmacia Biotech]) was added. After $2 \mathrm{~h}$ the plate was put on ice and cells were washed three times with PBS. Cells were lysed in $10 \mathrm{mM} \mathrm{NaH}_{2} \mathrm{PO}_{4}$, $\mathrm{pH} 7.4$, $1 \%$ Triton X-100, and $0.2 \%$ SDS and thereafter transferred to vials for scintillation counting.

\section{Results}

In a previous study we found that inhibition of РКC $\beta$ with LY379196 suppresses the proliferation and growth of SK$\mathrm{N}-\mathrm{BE}(2)$ cells [5]. In order to examine whether this is a cell line-specific effect, or if it is more general in terms of neuroblastoma cells, three neuroblastoma cell lines - IMR-32, SH-SY5Y, and SK-N-BE(2) - were cultured in the presence of increasing concentrations of LY379196 (Figure 1). This showed that all cell lines were sensitive to LY379196. At a concentration of $300 \mathrm{nM}$, LY379196 suppressed the number of viable cells with $16-24 \%$ for the three cell lines, which indicates that a PKC $\beta$ isoform has a positive effect on neuroblastoma cell growth.

To elucidate a putative synergistic effect of the PKC $\beta$ inhibitor and different anticancer drugs used for neuroblastoma therapy the three cell lines were cultured in the presence of increasing concentrations of doxorubicin, etoposide, paclitaxel, vincristine, or carboplatin together with different concentrations of LY379196 (Figure 2, Table 1). The cell lines displayed different sensitivity to the anticancer drugs. IMR-32 was consistently the most sensitive to all drugs investigated. SH-SY5Y and IMR-32 were equally sensitive to the topoisomerase inhibitors doxorubicin and etoposide whereas SH-SY5Y cells were three- to four-fold less sensitive to the microtubule interacting agents paclitaxel and vincristine and to the DNA 

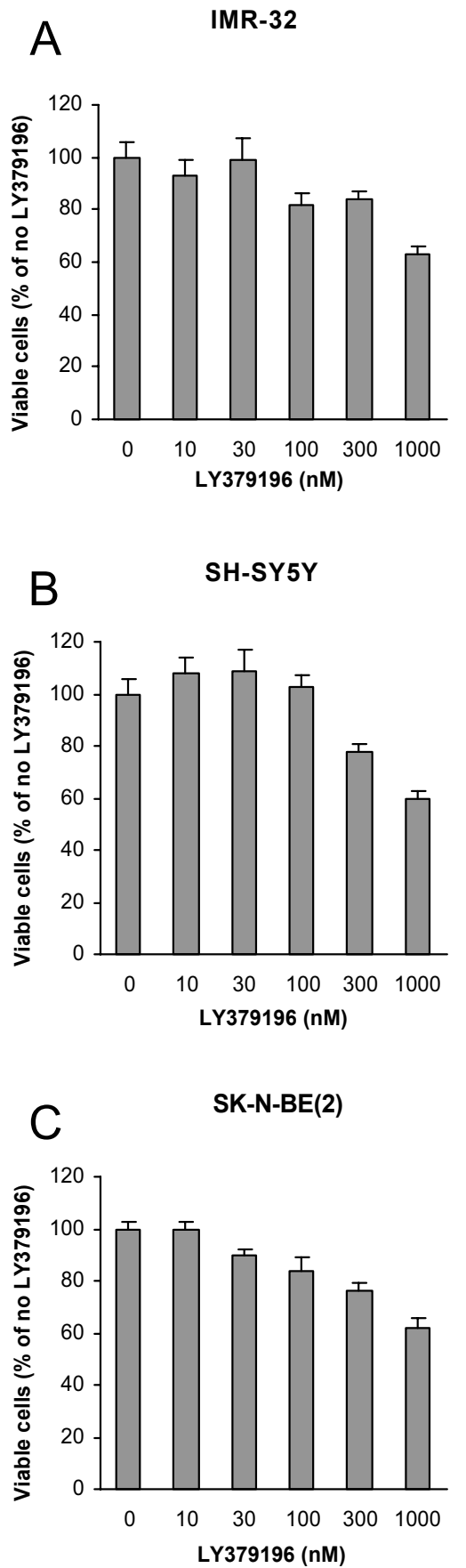

\section{Figure I}

Suppression of neuroblastoma cell growth by LY379 196. Neuroblastoma IMR-32 (A), SH-SY5Y (B), and SK-N-BE(2) (C) cells were grown for four (A and $B)$ or three (C) days in regular growth medium supplemented with increasing concentrations of LY379196. Thereafter the number of viable cells was determined with an MTT assay. Data are expressed as percent of values obtained in the absence of LY379196 and are mean \pm SEM $(n=9-18$ from 36 separate experiments). intercalator carboplatin. SK-N-BE(2) was the most resistant cell line being more than fifty-fold more resistant to doxorubicin, etoposide and carboplatin than the other cell lines. SK-N-BE(2) cells also displayed a substantially higher resistance to vincristine and paclitaxel.

When LY379196 was included in the medium there was a clear difference in effect depending on the cell line studied. For IMR-32, the least drug-resistant cell line, no effect of LY379196 on the potency of the chemotherapeutic drugs was observed. With $500 \mathrm{nM}$ there was a suppression of the number of viable cells but this reflects the inherent growth-suppressive effect of LY379196 (Figure 1) and was not due to an enhancement of the potency of anticancer agents on IMR-32 cells.

For SH-SY5Y cells, concomitant exposure to $500 \mathrm{nM}$ LY379196 led to approximately a doubling of the potency of doxorubicin, paclitaxel, and vincristine. The $\mathrm{ED}_{50}$ values were decreased from 9.3, 8.3 and $1.41 \mathrm{nM}$, respectively, in the absence of LY379196 to 5.0, 4.3 and $0.57 \mathrm{nM}$ (column A in Table 1), respectively, in the presence of 500 $\mathrm{nM}$ LY379196. These values reflect the potency of the chemotherapeutic drugs, since the growth-suppressing effect of LY379196 has been compensated for in the calculation. If the combined effect of $500 \mathrm{nM} \mathrm{LY379196}$ and the chemotherapeutic drugs is studied, the drug concentration necessary to suppress the number of viable cells to $50 \%$ of the amount obtained in the absence of both chemotherapeutic agent and LY379196 is further reduced to $2.0 \mathrm{nM}, 27 \mathrm{nM}$ and $0.33 \mathrm{nM}$ (column B in Table 1) for doxorubicin, paclitaxel and vincristine, respectively. This correlates to some degrees to the spectrum of drug resistance of SH-SY5Y cells compared to IMR-32 cells since SHSY5Y cells are more resistant to both paclitaxel and vincristine. However, no effect was observed on the potency of carboplatin, despite the fact that SH-SY5Y cells are less sensitive to this compound.

The effect of LY379196 was most pronounced on SK-N$\mathrm{BE}(2)$ cells, the cell line with the lowest sensitivity to the anticancer drugs. When $500 \mathrm{nM}$ LY379196 was included in the medium, there was an eight-fold decrease in the $\mathrm{ED}_{50}$ value of vincristine (from 42 to $5.2 \mathrm{nM}$ ), approximately a three-fold decrease of the values for doxorubicin (from 920 to $270 \mathrm{nM}$ ) and paclitaxel (from 117 to 40 $\mathrm{nM}$ ), and also an enhancement of the etoposide effect (column A in Table 1). These changes reflect an effect of LY379196 on the potency of the chemotherapeutic compounds since the inherent growth-inhibitory effect of LY379196 was compensated for in the calculations. As for SH-SY5Y cells, there was no effect of LY379196 on the cytotoxic/growth suppressive effect of carboplatin (Figure 2, Table 1). 

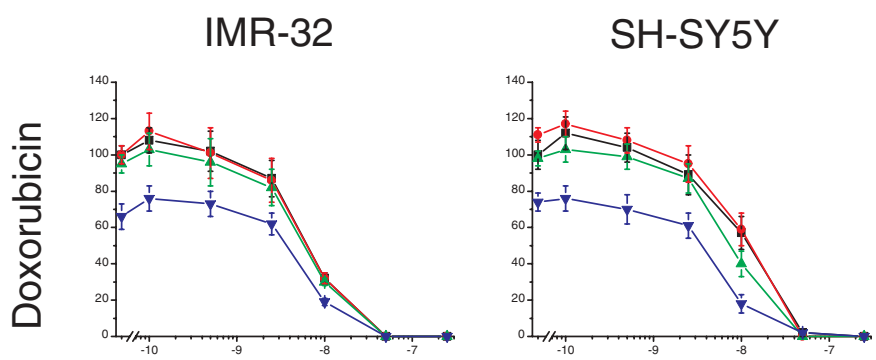

\section{SK-N-BE(2)}
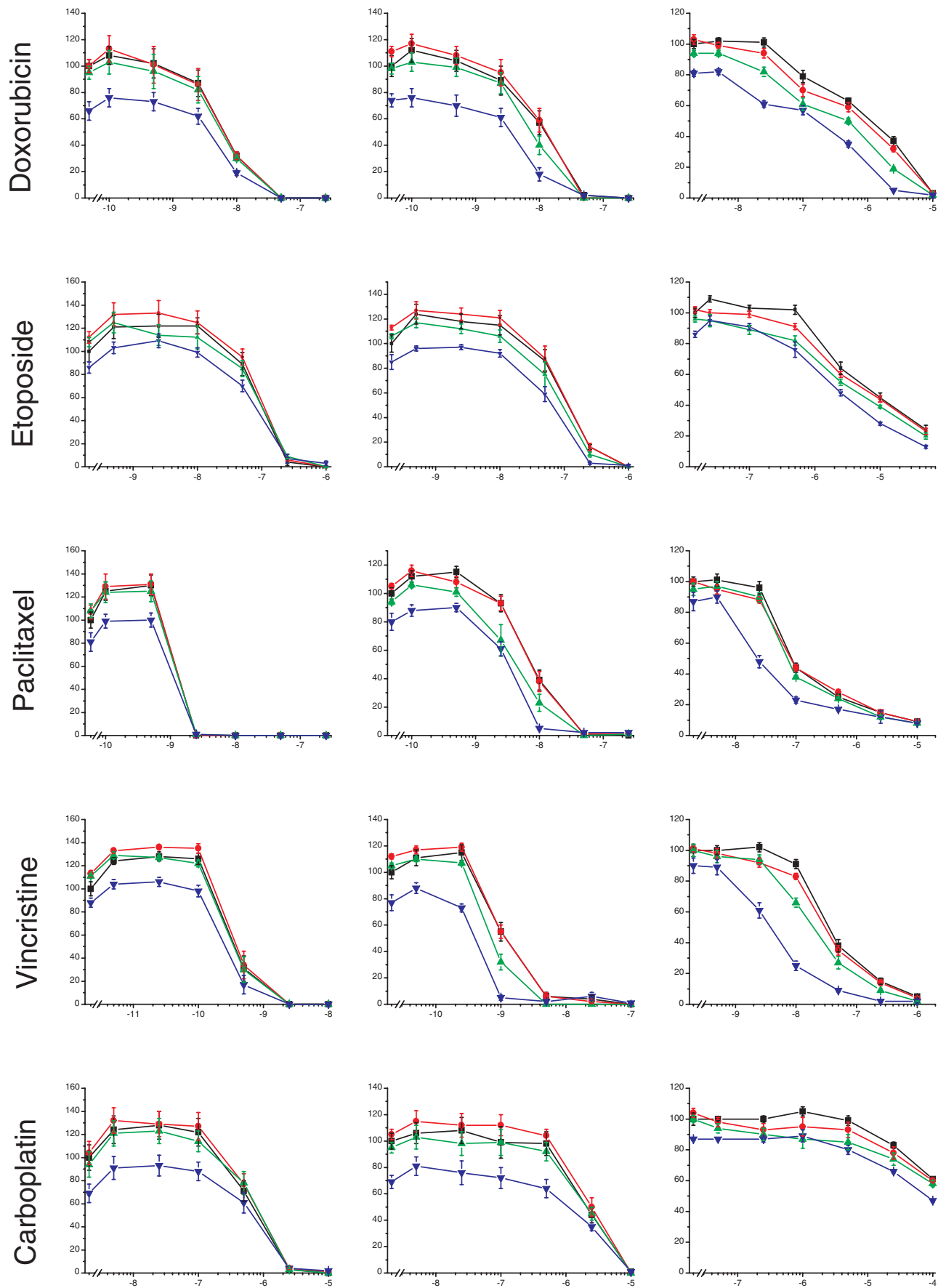

Figure 2

The effect of the combination of LY379I96 and anticancer drugs on neuroblastoma cell growth. IMR-32, SHSY5Y, and SK-N-BE(2) cells were grown in medium supplemented with increasing concentrations of doxorubicin, etoposide, paclitaxel, vincristine, and carboplatin. Different amounts of LY379/96 were also included in the medium yielding final concentrations of $0(\mathbf{\square}$, black), $20(\boldsymbol{\bullet}$, red), 100 ( $\mathbf{\Lambda}$, green) or 500 ( $\boldsymbol{\nabla}$, blue) nM. After three (SK-N-BE(2)) or four (IMR-32 and SHSY5Y) days in culture the amount of viable cells was analyzed with an MTT assay. The concentrations of the anticancer drugs are indicated on the $x$-axes as $\lg ([\mathrm{drug}] / \mathrm{IM})$. Data are expressed as percent of values obtained in the absence of drugs and are mean \pm SEM $(n=8-9)$. 
Table I: Effects of LY379196 on ED 50 values of chemotherapeutic drugs.

\begin{tabular}{|c|c|c|c|c|c|c|c|c|c|c|}
\hline \multirow{3}{*}{$\begin{array}{l}\text { IMR-32 } \\
\text { LY379|96 }\end{array}$} & \multicolumn{2}{|c|}{ Doxorubicin } & \multicolumn{2}{|c|}{ Etoposide } & \multicolumn{2}{|c|}{ Paclitaxel } & \multicolumn{2}{|c|}{ Vincristine } & \multicolumn{2}{|c|}{ Carboplatin } \\
\hline & \multicolumn{2}{|c|}{$(\mathrm{nM})$} & \multicolumn{2}{|c|}{$(n M)$} & \multicolumn{2}{|c|}{$(\mathrm{nM})$} & \multicolumn{2}{|c|}{$(\mathrm{nM})$} & \multicolumn{2}{|c|}{$(\mathrm{nM})$} \\
\hline & A & B & A & B & A & B & A & B & A & B \\
\hline $0 \mathrm{nM}$ & 6.3 & & 110 & & 1.7 & & 0.51 & & 760 & \\
\hline $20 \mathrm{nM}$ & 5.5 & 5.3 & 101 & 118 & 1.6 & 1.7 & 0.47 & 0.57 & 780 & 740 \\
\hline $100 \mathrm{nM}$ & 5.5 & 4.7 & 88 & 98 & 1.4 & 1.6 & 0.40 & 0.47 & 880 & 720 \\
\hline $500 \mathrm{nM}$ & 6.1 & 2.8 & 103 & 78 & 1.6 & 1.0 & 0.37 & 0.30 & 880 & 380 \\
\hline SH-SY5Y & \multicolumn{2}{|c|}{$(\mathrm{nM})$} & \multicolumn{2}{|c|}{$(n M)$} & \multicolumn{2}{|c|}{$(n M)$} & \multicolumn{2}{|c|}{$(n M)$} & \multicolumn{2}{|c|}{$(\mu M)$} \\
\hline LY379196 & $\mathbf{A}$ & B & $\mathbf{A}$ & B & $\mathbf{A}$ & B & $\mathbf{A}$ & B & $\mathbf{A}$ & B \\
\hline $0 \mathrm{nM}$ & 9.3 & & 109 & & 8.3 & & 1.41 & & 1.9 & \\
\hline $20 \mathrm{nM}$ & 8.2 & 9.8 & 93 & 114 & 7.3 & 8.0 & 1.20 & 1.45 & 2.2 & 2.3 \\
\hline $100 \mathrm{nM}$ & 7.2 & 6.7 & 74 & 81 & 4.8 & 4.3 & 0.82 & 0.89 & 2.1 & 1.8 \\
\hline $500 \mathrm{nM}$ & 5.0 & 2.0 & 75 & 55 & 4.3 & 2.7 & 0.57 & 0.33 & 2.0 & 0.7 \\
\hline SK-N-BE(2) & \multicolumn{2}{|c|}{$(\mathrm{nM})$} & \multicolumn{2}{|c|}{$(\mu M)$} & \multicolumn{2}{|c|}{$(\mathrm{nM})$} & \multicolumn{2}{|c|}{$(\mathrm{nM})$} & \multicolumn{2}{|c|}{$(\mu \mathrm{M})$} \\
\hline LY379196 & $\mathbf{A}$ & B & $\mathbf{A}$ & B & $\mathbf{A}$ & B & $\mathbf{A}$ & B & A & B \\
\hline $0 \mathrm{nM}$ & 920 & & 7.2 & & 117 & & 42 & & $>100$ & \\
\hline $20 \mathrm{nM}$ & 650 & 690 & 6.4 & 6.6 & 108 & 109 & 32 & 33 & $>100$ & $>100$ \\
\hline $100 \mathrm{nM}$ & 450 & 380 & 5.3 & 4.8 & 105 & 94 & 21 & 21 & $>100$ & $>100$ \\
\hline $500 \mathrm{nM}$ & 270 & 160 & 3.9 & 2.8 & 40 & 27 & 5.2 & 3.9 & $>100$ & $>100$ \\
\hline
\end{tabular}

This table shows the concentrations $\left(E_{50}\right)$ of the chemotherapeutic drugs, in the presence of different $L Y 379 / 96$ concentrations, needed to suppress the number of viable cells after three (SK-N-BE(2)) or four (IMR-32 and SH-SY5Y) days in culture to $50 \%$ of the amount obtained in the absence of the drug. The data used for calculations are obtained from Figure 2. Values are geometric mean of three separate experiments with triplicate measurements. The $\mathrm{ED}_{50}$ values were calculated using the amount of viable cells in the absence of chemotherapeutic drug but in the presence of LY379196 as 100\% (values in A columns) or the amount of viable cells in the absence of anticancer drug and LY379/96 (values in B columns). Thus, values in column $A$ reflect the potency of the chemotherapeutic drug since the inherent growth-suppressing effect of $L Y 379196$ has been eliminated in the calculations, whereas values in column B reflect the combined growth-suppressing effect of LY379/96 and chemotherapeutic drug. For carboplatin treatment of SK-N-BE(2) cells a reduction in viable cell amount by $50 \%$ was not obtained within the concentration range used.

If the potentiating effect on the chemotherapeutic drugs is mediated via an inhibition of РКС $\beta$ isoforms, other inhibitors of PKC would be expected to yield a similar effect. Therefore the effect of two PKC inhibitors, GF109203X which inhibits all PKC isoforms and Gö6976 which only inhibits classical isoforms, on the growth-inhibiting effects of vincristine on SK-N-BE(2) cells was investigated (Figure 3, Table 2). This experiment demonstrated that both these inhibitors increase the sensitivity of SK-N-BE(2) cells to vincristine. When the growth-suppressing effects of the inhibitors were compensated for, we found that the $\mathrm{ED}_{50}$ of vincristine was roughly halved in the presence of $500 \mathrm{nM}$ of either inhibitor (column A in Table 2). Gö6976 by itself also caused a substantial decrease of the amount viable cells.

The largest effect of LY379196 was observed for chemotherapeutic agents of the natural compound group and no effect was seen together with carboplatin. Resistance towards natural products has mostly been associated with a multidrug resistance phenotype, which has been suggested to be due to an increased expression of proteins, which pump out the compounds from the cells. To investigate whether inhibition of PKC $\beta$ influences this mechanism of resistance, the accumulation of $\left[{ }^{3} \mathrm{H}\right]$ vincristine was analyzed in the presence of increasing concentrations of PKC inhibitors (Figure 4). All inhibitors used (LY379196, GF109203X, and Gö6976) caused an enhancement of the accumulation of $\left[{ }^{3} \mathrm{H}\right]$ vincristine. The specific PKC $\beta$ inhibitor, LY379196, was the most potent compound and the concentrations which augmented the vincristine accumulation reflected the concentrations that sensitized the SK-N-BE(2) cells to vincristine.

\section{Discussion}

We have previously seen that inhibition of a РКC $\beta$ isoform, conceivably PKC $\beta I$, suppresses the proliferation of the SK-N-BE(2) neuroblastoma cell line [5]. The data in this study indicate that the proliferation supporting effect of a PKC $\beta$ isoform may be general for neuroblastoma cells since the growth of the two other cell lines tested also were sensitive to the PKC $\beta$ inhibitor. When $300 \mathrm{nM}$ LY379196 was included in the medium there were fewer cells after four days in culture of all cell lines suggesting that the effect may be general for neuroblastoma cells.

The data in this study also demonstrate that the РКС $\beta$ inhibitor augments the effect of natural product chemother- 

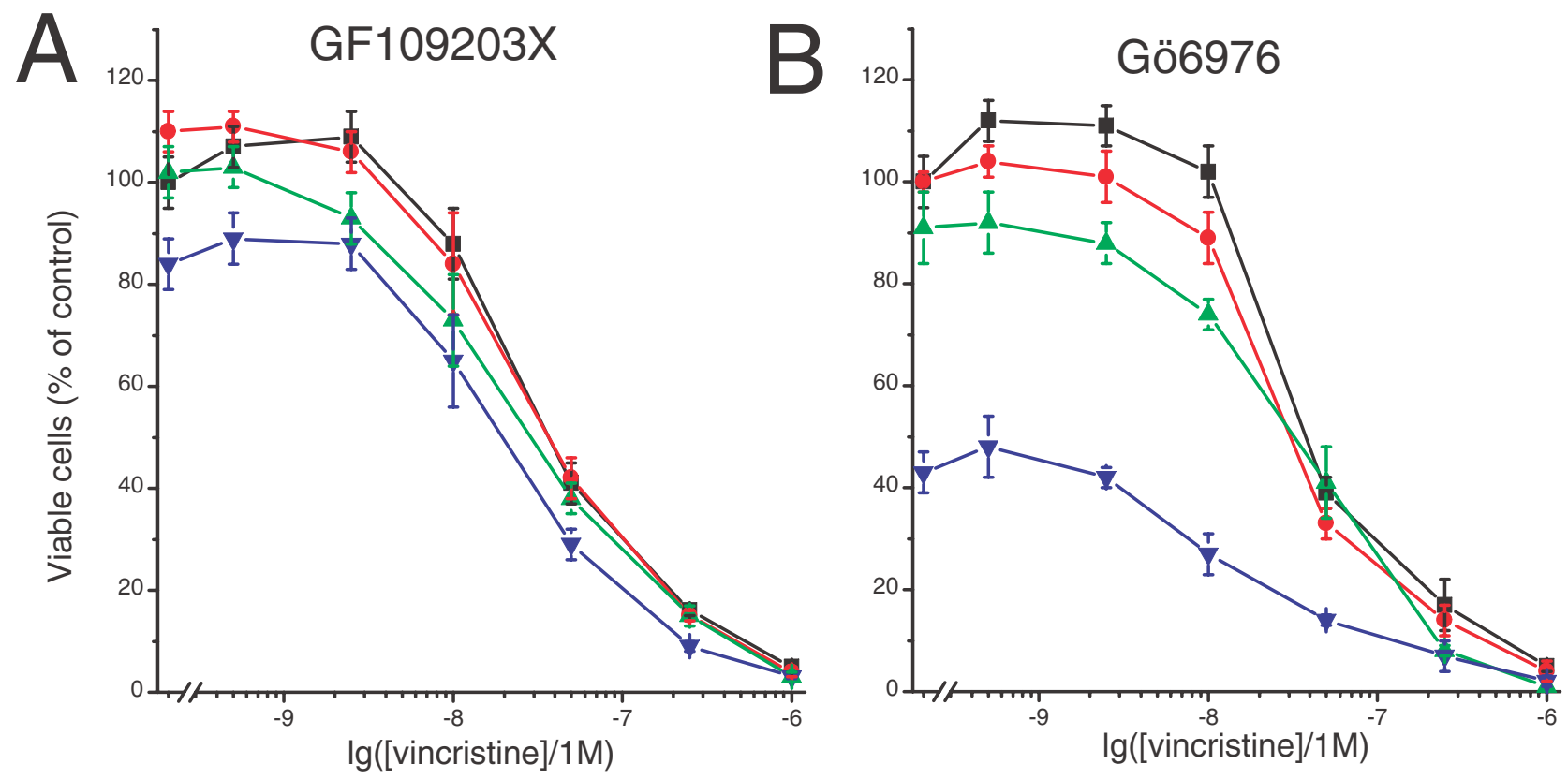

Figure 3

The effect of the combination of PKC inhibitors and vincristine on SK-N-BE(2) cell growth. SK-N-BE(2) cells were grown in medium supplemented with increasing concentrations of vincristine. Different amounts of GFI09203X (A) or Gö6976 (B) were also included in the medium yielding final concentrations of 0 ( $\square$, black), 20 ( $\boldsymbol{O}$, red), $100(\mathbf{A}$, green) or 500 $(\nabla$, blue) $\mathrm{nM}$. After three days in culture the amount of viable cells was analyzed with an MTT assay. The concentration of vincristine is indicated on the $x$-axes as $\lg ([\mathrm{drug}] / \mathrm{IM})$. Data are expressed as percent of values obtained in the absence of drugs and are mean \pm SEM $(n=8-9)$.

Table 2: Effects of GF $109203 X$ and $G 0 ̈ 6976$ on $E D_{50}$ values of vincristine.

\begin{tabular}{|c|c|c|c|c|}
\hline & \multicolumn{2}{|c|}{ GFI09203X } & \multicolumn{2}{|c|}{ Gö6976 } \\
\hline & \multicolumn{2}{|c|}{$(n M)$} & \multicolumn{2}{|c|}{$(\mathrm{nM})$} \\
\hline PKC inhibitor & $\mathbf{A}$ & B & $\mathbf{A}$ & B \\
\hline $0 \mathrm{nM}$ & 41 & & 49 & \\
\hline $20 \mathrm{nM}$ & 30 & 35 & 35 & 35 \\
\hline $100 \mathrm{nM}$ & 26 & 26 & 39 & 31 \\
\hline $500 \mathrm{nM}$ & 28 & 18 & 24 & NA \\
\hline
\end{tabular}

This table shows the concentrations $\left(\mathrm{ED}_{50}\right)$ of vincristine, in the presence of different concentrations of GFI09203X or Gö6976, needed to suppress the number of viable SK-N-BE(2) cells after three days in culture to $50 \%$ of the amount obtained in the absence of the drug. The data used for calculations are obtained from Figure 3. Values are geometric mean of three separate experiment with triplicate measurements. The $\mathrm{ED}_{50}$ values were calculated using the amount of viable cells in the absence of vincristine but in the presence of PKC inhibitor as $100 \%$ (values in A columns) or the amount of viable cells in the absence of vincristine and PKC inhibitor (values in B columns). Thus, values in column A reflect the potency of vincristine since the inherent growth-suppressing effect of the PKC inhibitors has been eliminated in the calculations, whereas values in column B reflect the combined growth-suppressing effect of PKC inhibitor and vincristine.NA - not available because culture in the presence of $500 \mathrm{nM}$ Gö6976 reduced the number of cells to less than $50 \%$ of the number obtained in the absence of the compound. 


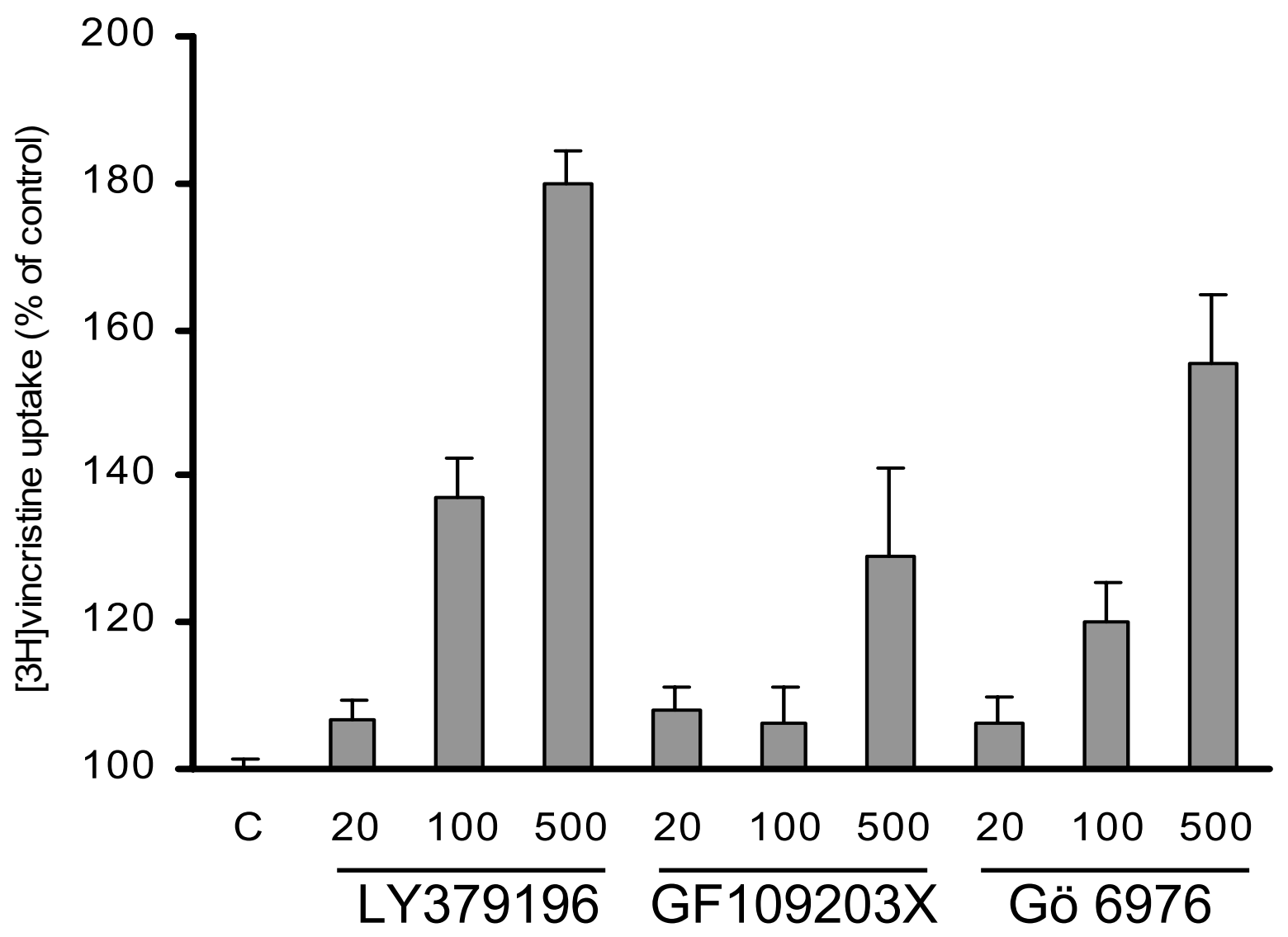

Figure 4

PKC inhibitors augment the accumulation of $\left[{ }^{3} \mathrm{H}\right]$ vincristine in SK-N-BE(2) cells. Different concentrations of LY379196, GFI09203X and Gö6976 were added to SK-N-BE(2) cells 15 min prior to a $2 \mathrm{~h}$ incubation with $\left[{ }^{3} \mathrm{H}\right]$ vincristine. The amount of the radioactivity that had accumulated in the cells was thereafter measured. Data are expressed as percent of $\left[{ }^{3} \mathrm{H}\right]$ vincristine that had accumulated in cells that had not been exposed to inhibitor and are mean \pm SEM of 8 determinations.

apeutic agents on multidrug-resistant neuroblastoma cells. In contrast to the effect on proliferation, which influenced all cell lines, the augmentation of the anticancer drugs was related to the grade of drug resistance of the cell line. It is therefore conceivable that LY379196 interferes with mechanisms that confer drug resistance to neuroblastoma cells, although it can not be excluded that other factors than the degree of drug resistance explain the difference in sensitivity to LY379196 in the presence of chemotherapeutic drugs.
The acquisition of multidrug resistance upon treatment with anti-cancer drugs is a common phenomenon for neuroblastomas [2]. This is a major reason for the high frequency of fatal outcome of the disease. Drug resistance of cancer cells has been suggested to be caused by increased expression of proteins of the ATP-binding cassette transporter family such as the MDR1 protein product Pglycoprotein and MRP. High expression of MDR1 in neuroblastomas was shown to be related to previous chemotherapeutic treatment [8], to drug resistance [9] and to bad prognosis in a subset of cases [10]. However, it was also shown to correlate inversely to MYCN amplification 
[11] and to good prognosis [12]. High expression of MRP has been reported to be prognostic for pour outcome [13] although other studies have not found this connection $[14,15]$. The expression of MRP is positively influenced by MYCN [16], which is frequently amplified in neuroblastomas with pour outcome. Thus, the specific role of the $M D R 1$ and MRP genes in the acquisition of drug-resistance of neuroblastomas has not yet been settled.

Another study has instead indicated a role for mutation and inactivation of the TP53 tumor suppressor gene in drug resistant neuroblastomas $[17,18]$. Furthermore a recent report has shown that chromosome reassortments can lead to drug resistance in cells that lack the MDR1 and $M R P 1$ genes that are thought to confer multidrug resistance [19].

The data in this study demonstrate a correlation between the potentiation of cytotoxic/growth suppressing effects of natural compound anti-cancer drugs and an enhancement of $\left[{ }^{3} \mathrm{H}\right]$ vincristine accumulation by PKC inhibitors in neuroblastoma cells. This suggests that the drug resistance of the SK-N-BE(2) cells is at least partially mediated by increased elimination of natural products by efflux pumps such as products of the MDR1 and MRP genes. This is supported by studies which have shown that agents that interfere with these pumps sensitizes drug resistant neuroblastoma cells to chemotherapeutic agents of the natural compound class [20,21]. Furthermore, LY379196 did not augment the effect of carboplatin, which is not a substrate for pumps of the P-glycoprotein family.

PKC activity was initially thought to support the activity of P-glycoprotein since it was shown to be a PKC substrate [22-24] and PKC inhibitors were reported to suppress the activity of the protein $[22,24,25]$. However, later studies demonstrated that phosphorylation of P-glycoprotein did not influence its function [26,27]. It has also been shown that GF109203X directly influences the activity of P-glycoprotein by competing with other substrates [28] and a similar mechanism of action has also been suggested for the effect of GF109203X on MRP [29] and for the reversal of drug resistance by the PKC inhibitor Ro 32-2241 [30]. The effect of LY379196 may therefore be due to a competition with the anticancer drugs for P-glycoprotein or other members of this family.

However, there are other reports demonstrating attenuating effects of PKC inhibitors on drug resistance that do not involve P-glycoprotein. Safingol and a myristoylated PKC pseudosubstrate peptide have been shown to inhibit PKC and potentiate drug accumulation independently of effects on P-glycoprotein [31-33]. The data in this study indicate that a PKC $\beta$ isoform could be a relevant isoform to inhibit in order to attenuate PKC-supported drug resist- ance. It is notable that the inhibitor with highest specificity for PKC $\beta$ also had the most profound effect on the cytotoxicity of vincristine. The smaller effect of the other inhibitors could for instance be due to inhibition of proapoptotic PKC isoforms such as PKC , which has been shown to be important for apoptosis in several cell types [34-38]. It should be noted that Gö6976 alone causes a substantial decrease of viable neuroblastoma cells, which may imply toxic effects attendant to the lack of isoform specificity. This could mask a potentiating effect on the cytotoxicity of vincristine and also preclude the use of Gö6976 at effective concentrations.

\section{Conclusions}

this study raises the potential to use PKC $\beta$ isoforms as targets to both partially suppress proliferation and to attenuate the multidrug resistance of neuroblastoma cells.

\section{Competing interests}

None declared.

\section{Author's Contributions}

KS carried out all experiments. CL was responsible for the progress of the work and preparation of the manuscript. Both authors read and approved the final manuscript.

\section{Acknowledgements}

Eli Lilly Research Laboratories are gratefully acknowledged for supplying LY379196. This work was supported by the Swedish Cancer Society, the Children's Cancer Foundation of Sweden, the Swedish Society for Medical Research, the Royal Physiographic Society of Lund, the Crafoord; Magnus Bergvall; Gunnar, Arvid and Elisabeth Nilsson; Ollie and Elof Ericsson; and Malmö University Hospital Research Funds.

\section{References}

I. Evans AE Neuroblastoma: A historical perspective I 864-I998 In: Neuroblastoma (Edited by: Brodeur GM, Sawada T, Tsuchida Y, Voûte PA) Amsterdam: Elsevier Science B.V 2000, I-7

2. Keshelava N, Seeger R, Groshen S and Reynolds $C$ Drug resistance patterns of human neuroblastoma cell lines derived from patients at different phases of therapy Cancer Res 1998, 58:53965405

3. Mellor $\mathrm{H}$ and Parker PJ The extended protein kinase $\mathbf{C}$ family Biochem J 1998, 332:281-292

4. Zeidman R, Pettersson L, Ranga PS, Truedsson E, Fagerström S, Påhlman $S$ and Larsson $C$ Novel and classical isoforms have different functions in proliferation, survival and differentiation of neuroblastoma cells Int J Cancer 1999, 81:494-501

5. Svensson K, Zeidman R, Trollér U, Schultz A and Larsson C PKC $\beta \mathbf{I}$ is implicated in the regulation of neuroblastoma cell growth and proliferation Cell Growth Differ 2000, I I:64 I-648

6. Zeidman R, Löfgren $B$, Påhlman $S$ and Larsson C PKC $\varepsilon$, via its regulatory domain and independently of its catalytic domain, induces neurite-like processes in neuroblastoma cells J Cell Biol 1999, I45:713-726

7. Zeidman R, Trollér U, Raghunath A, Påhlman S and Larsson C Protein kinase $C_{\varepsilon}$ actin-binding site is important for neurite outgrowth during neuronal differentiation Mol Biol Cell 2002, I3:12-24

8. Bourhis J, Benard J, Hartmann O, Boccon-Gibod L, Lemerle J and Riou $\mathrm{G}$ Correlation of MDR I gene expression with chemotherapy in neuroblastoma J Natl Cancer Inst 1989, 8 I: | 40 I-5 
9. Goldstein LJ, Fojo AT, Ueda K, Crist W, Green A, Brodeur G, Pastan $I$ and Gottesman MM Expression of the multidrug resistance, MDRI, gene in neuroblastomas J Clin Oncol 1990, 8: 128-36

10. Haber M, Bordow SB, Haber PS, Marshall GM, Stewart BW and Norris MD The prognostic value of MDRI gene expression in primary untreated neuroblastoma Eur J Cancer 1997, 33:203I-6

II. Nakagawara A, Kadomatsu K, Sato S, Kohno K, Takano H, Akazawa $K$, Nose $Y$ and Kuwano $M$ Inverse correlation between expression of multidrug resistance gene and $\mathrm{N}$-myc oncogene in human neuroblastomas Cancer Res 1990, 50:3043-7

12. Obana $K$ and Hashizume $K$ Expression of multidrug resistancerelated P-glycoprotein shows good prognosis in neuroblastoma J Pediatr Surg 1997, 32:420-2

13. Norris MD, Bordow SB, Marshall GM, Haber PS, Cohn SL and Haber $M$ Expression of the gene for multidrug-resistance-associated protein and outcome in patients with neuroblastoma $N$ Engl J Med 1996, 334:231-238

14. Matsunaga T, Shirasawa H, Hishiki T, Enomoto H, Kouchi K, Ohtsuka Y, Iwai J, Yoshida H, Tanabe M and Kobayashi S Expression of MRP and CMOAT in childhood neuroblastomas and malignant liver tumors and its relevance to clinical behavior Jpn J Cancer Res 1998, 89: 1276-83

15. Goto H, Keshelava N, Matthay KK, Lukens IN, Gerbing RB, Stram $\mathrm{DO}$, Seeger RC and Reynolds CP Multidrug resistance-associated protein I (MRPI) expression in neuroblastoma cell lines and primary tumors Med Pediatr Oncol 2000, 35:619-22

16. Haber M, Bordow SB, Gilbert J, Madafiglio J, Kavallaris M, Marshall GM, Mechetner EB, Fruehauf JP, Tee L and Cohn SL Altered expression of the MYCN oncogene modulates MRP gene expression and response to cytotoxic drugs in neuroblastoma cells Oncogene 1999, 18:2777-82

17. Tweddle DA, Malcolm AJ, Bown N, Pearson ADJ and Lunec J Evidence for the development of $\mathrm{p} 53$ mutations after cytotoxic therapy in a neuroblastoma cell line Cancer Res 200I, 6I:8-13

18. Keshelava N, Zuo JJ, Chen P, Waidyaratne SN, Luna MC, Gomer CJ, Triche TJ and Reynolds CP Loss of p53 function confers high-level multidrug resistance in neuroblastoma cell lines Cancer Res 200I, 6I:6185-6193

19. Duesberg $P$, Stindl $R$ and Hehlmann $R$ Origin of multidrug resistance in cells with and without multidrug resistance genes: Chromosome reassortments catalyzed by aneuploidy Proc Natl Acad Sci USA 200 I, 98: I I 283- I I 288

20. Yanagisawa T, Newman A, Coley H, Renshaw J, Pinkerton CR and Pritchard-Jones K BIRICODAR (VX-7I0; Incel): an effective chemosensitizer in neuroblastoma Br / Cancer 1999, 80:1190-6

21. Norris MD, Madafiglio J, Gilbert J, Marshall GM and Haber M Reversal of multidrug resistance-associated protein-mediated drug resistance in cultured human neuroblastoma cells by the quinolone antibiotic difloxacin Med Pediatr Oncol 200I, 36:177-80

22. Chambers TC, McAvoy EM, Jacobs JW and Eilon G Protein kinase $C$ phosphorylates $\mathrm{P}$-glycoprotein in multidrug resistant human KB carcinoma cells J Biol Chem 1990, 265:7679-86

23. Blobe GC, Sachs CW, Khan WA, Fabbro D, Stabel S, Wetsel WC, Obeid LM, Fine RL and Hannun YA Selective regulation of expression of protein kinase $C$ (PKC) isoenzymes in multidrugresistant MCF-7 cells. Functional significance of enhanced expression of PKC alpha J Biol Chem 1993, 268:658-64

24. Bates SE, Lee JS, Dickstein B, Spolyar M and Fojo AT Differential modulation of P-glycoprotein transport by protein kinase inhibition Biochemistry 1993, 32:9156-64

25. Ma LD, Marquardt D, Takemoto $L$ and Center MS Analysis of $\mathbf{P}$ glycoprotein phosphorylation in HL60 cells isolated for resistance to vincristine J Biol Chem I99|, 266:5593-9

26. Germann UA, Chambers TC, Ambudkar SV, Licht T, Cardarelli CO, Pastan I and Gottesman MM Characterization of phosphorylation-defective mutants of human P-glycoprotein expressed in mammalian cells / Biol Chem 1996, 271:|708-17|6

27. Goodfellow HR, Sardini A, Ruetz S, Callaghan R, Gros P, McNaughton $\mathrm{PA}$ and Higgins CF Protein kinase C-mediated phosphorylation does not regulate drug transport by the human multidrug resistance P-glycoprotein J Biol Chem 1996, 27 I: I 3668-I 13674

28. Gekeler V, Boer R, Uberall F, Ise W, Schubert C, Utz I, Hofmann J, Sanders $\mathrm{KH}$, Schachtele $\mathrm{C}$ and Klemm K Effects of the selective bisindolylmaleimide protein kinase C inhibitor GF 109203X on P-glycoprotein-mediated multidrug resistance $\mathrm{Br}$ / Cancer 1996, 74:897-905
29. Gekeler V, Boer R, Ise W, Sanders KH, Schachtele C and Beck J The specific bisindolylmaleimide PKC-inhibitor GF $109203 \mathrm{X}$ efficiently modulates MRP-associated multiple drug resistance Biochem Biophys Res Commun 1995, 206: I 19-26

30. Merritt JE, Sullivan JA, Drew L, Khan A, Wilson K, Mulqueen M, Harris W, Bradshaw D, Hill CH and Rumsby $M$ The bisindolylmaleimide protein kinase $\mathbf{C}$ inhibitor, Ro 32-reverses multidrug resistance in KB tumour cells Cancer Chemother Pharmacol 1999, 43:37I-8

31. Sachs CW, Safa AR, Harrison SD and Fine RL Partial inhibition of multidrug resistance by safingol is independent of modulation of P-glycoprotein substrate activities and correlated with inhibition of protein kinase C J Biol Chem 1995, 270:2663926648

32. Bergman PJ, Gravitt KR, Ward NE, Beltran P, Gupta KP and O'Brian $C A$ Potent induction of human colon cancer cell uptake of chemotherapeutic drugs by $\mathrm{N}$-myristoylated protein kinase C-alpha (PKC-alpha) pseudosubstrate peptides through a Pglycoprotein-independent mechanism Invest New Drugs 1997, | 5:3| |-8

33. Bergman PJ, Gravitt KR and O'Brian CA An N-myristoylated protein kinase $\mathrm{C}$-alpha pseudosubstrate peptide that functions as a multidrug resistance reversal agent in human breast cancer cells is not a P-glycoprotein substrate Cancer Chemother Pharmacol 1997, 40:453-6

34. Ghayur T, Hugunin M, Talanian RV, Ratnofsky S, Quinlan C, Emoto Y, Pandey P, Datta R, Huang $Y$ and Kharbanda S Proteolytic activation of protein kinase $C \delta$ by an ICE/CED 3-like protease induces characteristics of apoptosis J Exp Med 1996, 184:2399. 2404

35. Majumder PK, Pandey P, Sun X, Cheng K, Datta R, Saxena S, Kharbanda $S$ and Kufe D Mitochondrial translocation of protein kinase $C$ delta in phorbol ester-induced cytochrome $c$ release and apoptosis J Biol Chem 2000, 275:21793-6

36. Reyland ME, Anderson SM, Matassa AA, Barzen KA and Quissell DO Protein kinase $C$ delta is essential for etoposide-induced apoptosis in salivary gland acinar cells J Biol Chem I999, 274: I9 II519123

37. Fujii T, Garcia-Bermejo ML, Bernabo JL, Caamano J, Ohba M, Kuroki $\mathrm{T}$, Li L, Yuspa SH and Kazanietz MG Involvement of protein Kinase C delta (PKCdelta) in phorbol ester-induced apoptosis in LNCaP prostate cancer cells. Lack of proteolytic cleavage of PKCdelta J Biol Chem 2000, 275:7574-7582

38. Khwaja $A$ and Tatton $L$ Caspase-mediated proteolysis and activation of protein kinase Cdelta plays a central role in neutrophil apoptosis Blood 1999, 94:29|-30I

\section{Pre-publication history}

The pre-publication history for this paper can be accessed here:

\section{http://www.biomedcentral.com/1471-2407/3/10/prepub}

Publish with Biomed Central and every scientist can read your work free of charge

"BioMed Central will be the most significant development for disseminating the results of biomedical research in our lifetime. "

Sir Paul Nurse, Cancer Research UK

Your research papers will be:

- available free of charge to the entire biomedical community

- peer reviewed and published immediately upon acceptance

- cited in PubMed and archived on PubMed Central

- yours - you keep the copyright

Submit your manuscript here:

http://www.biomedcentral.com/info/publishing_adv.asp
BioMedcentral 